\title{
Nephrocurative Effect of Aqueous Stem Bark Extract of Cassia Sieberiana on Rats Induced Kidney Damage
}

\author{
Samira A. Abdullahi \\ Department of Computing and Applied Sciences, Baze University, FCT Abuja, Nigeria. Email: sameerageidam@gmail.com \\ Copyright: @2020 Samira A.Abdullahi. This is an open access article distributed under the terms of the Creative Commons Attribution License, which permits \\ unrestricted use, distribution, and reproduction in any medium, provided the original author and source are credited.
}

Traditional drugs are the most easily and affordable source of treatment in Nigeria. Different parts of Cassia sieberiana have been shown to exhibi wide pharmacological activities. Acute toxicity and effect of aqueous stem bark extract of Cassia sieberiana in rats induced acetaminophen kidney damaged were conducted. Rats were divided into eight groups, groups ii to viii were induced with acetaminophen at the dose of $800 \mathrm{mg} / \mathrm{kg}$ for nephrotoxicity, followed by the administration of the extract from group iii to viii at the doses of 50,100 and $150 \mathrm{mg} / \mathrm{kg}$ for two and four weeks respectively. Group i (control) and ii (acetaminophen administered rats) were sacrificed after 48 hours of the induction, group iii to viii were sacrificed after two and four weeks of the extract administration, the blood samples were collected to determine serum levels of urea, creatinine, $\mathrm{Na}^{+}$ $\mathrm{K}^{+}, \mathrm{Cl}^{-}, \mathrm{HCO}_{3}^{-}$. The results, showed significant $\left(\mathrm{p}<0.05\right.$ ) increase in the serum levels of urea, creatinine, $\mathrm{Na}^{+}, \mathrm{K}^{+}, \mathrm{Cl}^{-}, \mathrm{HCO}_{3}^{-}$in group ii as compared to group i. The results of the effect of aqueous stem bark extract of Cassia sieberiana administration at the doses of 50,100 and $150 \mathrm{mg} / \mathrm{kg}$ for both two and four weeks showed a significant $(\mathrm{p}<0.05)$ decrease in the serum levels of urea, creatinine, $\mathrm{Na}^{+}, \mathrm{K}^{+}, \mathrm{Cl}^{-}, \mathrm{HCO}_{3}{ }^{-}$as compared to group ii. The histopathological examination of the kidney nephrocytes of the curative effect of extract of Cassia sieberiaba was conducted to confirm the effect of the extract on the biochemical parameters. The results of the biochemical parameters above indicated some nephrocurative effects of the extract against acetaminophen induced toxicities.

Keywords: Traditional medicine, Cassia sieberiana, Nephrotoxicity, Acetaminophen, Histopatology.

\section{Introduction}

Medicinal plants are used for the management of various disease. Herbal therapies today are used by millions of people along with prescription and nonprescription medications (Ramesh et al., 2017). Chemical substances with different pharmacological and biological activities are produced naturally by Plants (Bourhia et al., 2019). Rural and tribal communities adapt the use of plant with medicinal properties (Nisar et al., 2018). The ability of the plant to synthesize many compounds gives them their pharmacological effect. About $80 \%$ of the world population relies on herbal medicine (Obidah et al., 2009). Paracetamol is a widely used drug with analgesic and antipyretic properties (Sasikala et al., 2019).From the gastrointestinal tract, Paracetamol produces side effect and the action of it include effect of both the peripheral (COX inhibition), and central (COX, serotonergic descending neuronal pathway, L-arginine/NO pathway, cannabinoid system) antinociception processes and ìredoxî mechanism. Paracetamol is well tolerated drug and produces few side effects from the (Marta et al.,2014) IN over dose of paracetamol leads to hepatotoxicity and nephrotoxicity, Even if nephrotoxicity is less common than hepatotoxicity in PCM overdose, renal tubular damage and acute renal failure can occur even in the absence of liver injury.

Cassia sieberiana (D.C.) is a common plant found in saharan and sub sharan Africa.it is known as MALGA in Hausa Language. It belongs to the Family; Caesalpiniaceae Leguminosae. Some part of the plants is used for treatment of jaundice, inflammatory conditions, rheumatism, malaria deworming (Abdulrazak et al., 2015). After child birth, it improves lactation. The stem bark of the plant has hepatocurative effect (Obidah et al., 2009).The root of plant has antiplasmodium, analgesic, antinflamatory and antiparasitic activities (Donkor et al., 2014). The role of

Kidney in metabolic process involves maintenance of homoestasis by reabsorbing substance and waste product 
Asian Journal of Applied Science and Technology

Volume 4, Issue 4, Pages 85-94, October-December 2020

excretion. Nephrotoxicity is one of the major health problems and greatest health challenges faced by world's population (Donkor et al., 2014).It occur when the endogenous or exogenous toxicans damage or destroy the kidney. These affect excretion and detoxification of the kidney (Sasikala et al., 2019).High incidence of kidney diseases causes death among the adult population globally (Kuppuswamy et al., 2003). Most of the drugs used in treatment of kidney disease are sometimes expensive and have a serious adverse effect, it is therefore important to search for alternative drugs for the treatment of kidney diseases to replace currently used drugs of doubtful efficacy and safety. This study was aimed at evaluating the effect Of Aqueous Stem Bark Extract of Cassia Sieberiana On Rats Induced Nephrotoxicity.

\section{Material and methods}

\subsection{Acute toxicity}

The $\mathrm{LD}_{50}$ was determined using lorke method (1983). Nine (9) albino rats were used in the initial phase in which the rats were divided into 3 groups, each group containing three rats. The animals were treated with the aqueous stem bark extract of Cassia sieberiana 50,100 and $1000 \mathrm{mg} / \mathrm{kg}$ and were monitored for $24 \mathrm{hrs}$, for mortality and general behaviour. In phase II, four (4) rats were used and grouped into four (4) groups of one rat each. They were treated with aqueous stem bark extract of Cassia sieberiana at doses of $1500,2500,3500,5000 \mathrm{mg} / \mathrm{Kg}$ orally. They were monitored again for $24 \mathrm{hrs}$

\subsection{Experimental Animals}

The experimental animals (37 rats) were purchased from zoological Department of Bayero University Kano. The rats were placed under standard condition and fed standard (vital feed) diet and water ad libitum. The experiments were performed according to the principles of laboratory animal care.

\subsection{Collection, Identification and Preparation of the Plant Extract}

Cassia sieberiana stem bark was collected from Gwarzo town area, Kano state. It was identified at Biological Science Department of Bayero University Kano.

The stem bark was washed in distilled water and dried at room temperature. The bark was then grounded into a powder and $100 \mathrm{~g}$ of the powder was weighed and soaked in $400 \mathrm{~cm}^{3}$ of distilled water for $24 \mathrm{hrs}$.

The extract was filtered using whatman filter paper no (1), the filtrate was dried. The weight of the stem bark extract was measured.

The dried extract was reconstituted and volume of the extract to be administered was determined based on the weight of the rats and required dose, using the relation.

$\operatorname{Vol}\left(\mathrm{cm}^{3}\right)=\frac{\text { Weight of the rat }(\mathrm{kg}) \times \operatorname{dose}(\mathrm{mg} / \mathrm{kg})}{\text { Concentration of the extract }\left(\mathrm{mg} / \mathrm{cm}^{3}\right)}$

\subsection{Acute toxicity}

The $\mathrm{LD}_{50}$ was determined using lorke method (1983) 


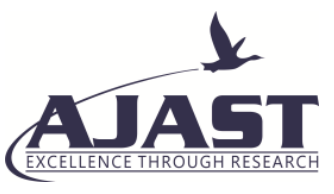

Asian Journal of Applied Science and Technology Volume 4, Issue 4, Pages 85-94, October-December 2020

\subsection{Experimental Design}

A total of 37 rats were used for this research. Thirteen (13) rats were used for evaluation of the acute toxicity,and twenty four (24) were used to evaluate the effect of aqueous stem bark extract of Cassia sieberiana on kidney damage (medicinal property).

\subsection{Induction of kidney damage}

Kidney damage was induced by injection of $800 \mathrm{mg} / \mathrm{kg}$ of acetaminophen to the albino rats according to Adeneye $e t$ al (2008) after 48 hrs. The dose of acetaminophen administered was determined by the weight of the rat according to the following relation; serum and kidney specimens were collected and analysed for confirmation of induction.

$\operatorname{Vol}\left(\mathrm{cm}^{3}\right)=\frac{\text { Weight of rat }(\mathrm{kg}) \times 800 \mathrm{mg} / \mathrm{kg}}{\text { Concentration of acetaminophen solution }(150 \mathrm{mg} / \mathrm{ml})}$

\subsection{Assessment of the potential curative effect of the C.S on kidney damage}

Twenty four (24) experimental rats were divided into eight groups of three rats each. Kidney toxicity was induced in groups ii- viii using $800 \mathrm{mg} / \mathrm{kg}$ acetaminophen according to adeneye et al (2008).

Group I; (normal).

Group ii; acetaminophen administered, no extract (test control).

Group iii; were administered with aqueous stem bark extract of Cassia sieberiana (dose; 50mg/kg for two weeks). Group iv; were administered with aqueous stem bark extract of Cassia sieberiana (dose; 100mg/kg for two weeks). Group v; were administered with aqueous stem bark extract of Cassia sieberiana (dose; $150 \mathrm{mg} / \mathrm{kg}$ for two weeks). Group vi; were administered with aqueous stem bark extract of Cassia sieberiana (dose; 50mg/kg for four weeks). Group vii; were managed with aqueous stem bark extract of Cassia sieberiana (dose; $100 \mathrm{mg} / \mathrm{kg}$ for four weeks).

Group viii; were managed with aqueous stem bark extract of Cassia sieberiana (dose; $150 \mathrm{mg} / \mathrm{kg}$ for four weeks). Groups i and ii were sacrificed after 24hours of acetaminophen administration. Groups iii-v was sacrificed after two weeks of the extract administration while groups vi- viii were sacrificed after 4 weeks of the treatment. Blood samples were collected for the analysis of creatinine, urea, and electrolytes $\left(\mathrm{Na}^{+}, \mathrm{K}^{+}, \mathrm{Cl}^{-}\right.$and $\left.\mathrm{HCO}_{3}{ }^{-}\right)$.

\subsection{Kidney function test}

Urea, creatinine and electrolytes $(\mathrm{Na}+, \mathrm{Cl}-\mathrm{K}+, \mathrm{HCO} 3-)$ levels in the serum of treated rats were evaluated using assay Randox Laboratories kits (Randox Laboratories LTD, United Kingdom, BT29 4QY).

\subsection{Histopathological Studies}

The kidney specimens of the sacrificed rats were transported in $10 \%$ buffered formalin to the Histopathology department of Aminu Kano Teaching Hospital, Kano, where histopathological analysis was conducted according to (Auwioro, 2010; Mitchell et al., 2011). 


\section{A. Statistical analysis}

The data was statistically analysed using One-way Analysis of Variance (ANOVA) with P value 0.05 considered extremely significant.

\section{Results}

Table 1: Phase I LD50, (Oral, rat) determination of the aqueous stem bark extract of Cassia sieberiana

\begin{tabular}{|c|c|}
\hline $\operatorname{Doses}(\mathbf{m g} / \mathbf{k g})$ & Mortality \\
\hline $\mathbf{1 0}$ & $0 / 3$ \\
\hline $\mathbf{1 0 0}$ & $0 / 3$ \\
\hline $\mathbf{1 0 0 0}$ & $0 / 3$ \\
\hline
\end{tabular}

Table 2: Phase II LD50, (Oral, rat) determination of the aqueous stem bark extract of Cassia sieberiana

\begin{tabular}{|c|c|}
\hline $\operatorname{Doses}(\mathbf{m g} / \mathbf{k g})$ & Mortality \\
\hline $\mathbf{1 5 0 0}$ & $0 / 1$ \\
\hline $\mathbf{2 5 0 0}$ & $0 / 1$ \\
\hline $\mathbf{3 5 0 0}$ & $0 / 1$ \\
\hline $\mathbf{5 0 0 0}$ & $0 / 1$ \\
\hline
\end{tabular}

Table 3: Effect of ASBEC on the serum levels of urea, creatinine and electrolytes ( $\mathrm{Na}+, \mathrm{Cl}-, \mathrm{K}+, \mathrm{HCO} 3-)$ in the rats induced with acetaminophen injury after two weeks of extract administration

\begin{tabular}{|c|c|c|c|c|c|c|}
\hline Group/doses(mg/kg & $\mathrm{Na}^{+}(\mathbf{m m o l} / \mathbf{l})$ & $\mathbf{K}^{+}(\mathbf{m m o l} / \mathbf{l})$ & HCO3(mmol) & $\mathrm{Cl}^{-}(\mathrm{mmol} / \mathrm{l})$ & Urea(mmol) & $\mathrm{Cr}(\mathrm{mmol} / \mathrm{l})$ \\
\hline i (untreated rats) & $122.23 \pm 2.06^{\text {b,c,d }}$ & $4.57 \pm 0.32^{\mathrm{b}, \mathrm{c}, \mathrm{d}}$ & $17.57 \pm 0.75^{\text {,b,c,d }}$ & $88.07 \pm 0.21^{, \mathrm{b}, \mathrm{c}, \mathrm{d}}$ & $24.47 \pm 1.39^{\text {b,c, d }}$ & $38.30 \pm 1.13^{, \mathrm{b}, \mathrm{c}, \mathrm{d}}$ \\
\hline $\begin{array}{l}\text { ii (acetaminophen treated } \\
\text { rats, } 800 \mathrm{mg} / \mathrm{kg} \text { administered }\end{array}$ & $157.03 \pm 1.6^{\mathrm{e}, \mathrm{f}, \mathrm{g}}$ & $11.43 \pm 0.31^{, \mathrm{fg}, \mathrm{h}}$ & $30.00 \pm 2.65^{\mathrm{e}}$ & $130.77 \pm 1.29^{\mathrm{f}, \mathrm{g}, \mathrm{h}}$ & $97.83 \pm 0.47^{\mathrm{h}, \mathrm{I}, \mathrm{j}}$ & $68.37 \pm 0.71^{\mathrm{g}, \mathrm{h}, \mathrm{i}}$ \\
\hline $\begin{array}{l}\text { iii (acetaminophen+50mg/kg } \\
\text { of extract) }\end{array}$ & $130.50 \pm 1.48^{\mathrm{b}, \mathrm{e}}$ & $6.87 \pm 0.68^{\mathrm{b}, \mathrm{f}}$ & $26.97 \pm 2.75^{b}$ & $109.50 \pm 0.44^{\mathrm{b}, \mathrm{f}}$ & $55.43 \pm 1.03^{\mathrm{b}, \mathrm{h}}$ & $49.03 \pm 1.84^{\mathrm{b}, \mathrm{g}}$ \\
\hline $\begin{array}{l}\text { vi (acetaminophen }+100 \mathrm{mg} / \mathrm{kg} \\
\text { of extract) }\end{array}$ & $128.30 \pm 0.80^{\mathrm{c}, \mathrm{f}}$ & $6.43 \pm 0.21^{\mathrm{c}, \mathrm{g}}$ & $25.10 \pm 2.91^{\mathrm{c}}$ & $101.43 \pm 0.40^{\mathrm{c}, \mathrm{g}}$ & $50.23 \pm 0.95^{\mathrm{c}, \mathrm{i}}$ & $46.10 \pm 1.01^{\mathrm{c}, \mathrm{h}}$ \\
\hline $\begin{array}{l}\mathrm{v} \text { (acetaminophen }+150 \mathrm{mg} / \mathrm{kg} \\
\text { of extract) }\end{array}$ & $125.80 \pm 0.56^{\mathrm{d}, \mathrm{g}}$ & $5.83 \pm 0.25^{\mathrm{d}, \mathrm{h}}$ & $20.23 \pm 1.25^{\mathrm{d}, \mathrm{e}}$ & $98.20 \pm 1.56^{\mathrm{d}, \mathrm{h}}$ & $45.30 \pm 1.48^{\mathrm{d}, \mathrm{j}}$ & $43.00 \pm 1.01^{\mathrm{d}, \mathrm{i}}$ \\
\hline
\end{tabular}

Results are expressed as mean $\pm S D$ for three determinations, $n=3$ 


\section{A. IAST}

Asian Journal of Applied Science and Technology

Volume 4, Issue 4, Pages 85-94, October-December 2020

Values in the same column bearing the same superscript are significantly different at $\mathrm{P}<0.05$ when compared with group i (untreated group) and group ii (acetaminophen treated group)

Table 4: Effect of ASBEC on the serum levels of urea, creatinine and electrolytes (Na+, $\mathrm{Cl}-, \mathrm{K}+, \mathrm{HCO}-)$ in the rats induced with acetaminophen injury after four weeks of extract administration

\begin{tabular}{|c|c|c|c|c|c|c|}
\hline Group/doses $(\mathrm{mg} / \mathrm{kg}$ & $\mathrm{Na}^{+}(\mathbf{m m o l} / \mathrm{l})$ & $\mathbf{K}^{+}(\mathbf{m m o l} / \mathbf{l})$ & $\mathrm{HCO}_{3}^{-}(\mathrm{mmol} /)$ & $\mathrm{Cl}^{-}(\mathrm{mmol} / \mathrm{l})$ & Urea(mmol/l) & $\mathrm{Cr}(\mathrm{mmol} / \mathrm{l})$ \\
\hline i (untreated rats) & $122.23 \pm 2.06$ & $4.57 \pm 0.32^{\mathrm{e}}$ & $17.57 \pm 0.75$ & $88.07 \pm 0.21^{\mathrm{e}}$ & $24.47 \pm 1.39^{\mathrm{e}, \mathrm{f}, \mathrm{g}}$ & $38.30 \pm 1.13^{\mathrm{e}, \mathrm{f}}$ \\
\hline $\begin{array}{l}\text { ii (acetaminophen } \\
\text { treated rats } 800 \mathrm{mg} / \mathrm{kg}\end{array}$ & $157.03 \pm 1.68^{\mathrm{h}, \mathrm{I}, \mathrm{j}}$ & $11.43 \pm 0.31^{\mathrm{i}, \mathrm{j}, \mathrm{k}}$ & $30.00 \pm 2.65^{\mathrm{i}, \mathrm{j}, \mathrm{k}}$ & $130.77 \pm 1.29^{\mathrm{f}, \mathrm{g}, \mathrm{h}}$ & $97.83 \pm 0.47^{\mathrm{k}, \mathrm{l}, \mathrm{m}}$ & $68.37 \pm 0.71^{\mathrm{j}, \mathrm{k}, \mathrm{l}}$ \\
\hline $\begin{array}{l}\text { vi (acetaminophen+ } \\
50 \mathrm{mg} / \mathrm{kg} \text { extract) }\end{array}$ & $124.97 \pm 0.46^{\mathrm{h}}$ & $5.37 \pm 0.15^{\mathrm{e}, \mathrm{i}}$ & $19.67 \pm 1.53^{\mathrm{i}}$ & $96.73 \pm 0.32^{\mathrm{e}, \mathrm{f}}$ & $43.63 \pm 0.91^{\mathrm{e}, \mathrm{k}}$ & $42.93 \pm 0.67^{\mathrm{e}, j}$ \\
\hline $\begin{array}{l}\text { vii (acetaminophen+ } \\
100 \mathrm{mg} / \mathrm{kg} \text { of extract) }\end{array}$ & $122.77 \pm 0.60^{\mathrm{i}}$ & $4.87 \pm 0.21^{\mathrm{j}}$ & $17.07 \pm 1.10^{\mathrm{j}}$ & $91.87 \pm 0.47^{\mathrm{g}}$ & $32.57 \pm 0.21^{\mathrm{f}, 1}$ & $40.47 \pm 0.25^{\mathrm{f}, \mathrm{k}}$ \\
\hline $\begin{array}{l}\text { viii (acetaminophen+ } \\
150 \mathrm{mg} / \mathrm{kg} \text { extract) }\end{array}$ & $122.33 \pm 0.21^{\mathrm{j}}$ & $4.43 \pm 0.31^{\mathrm{k}}$ & $16.73 \pm 0.67^{\mathrm{k}}$ & $89.77 \pm 0.55^{\mathrm{h}}$ & $28.47 \pm 1.26^{\mathrm{g}, \mathrm{m}}$ & $39.20 \pm 0.26^{1}$ \\
\hline
\end{tabular}

Results are expressed as mean \pm SD for three determinations, $n=3$. Values in the same column bearing the same superscript are significantly different at $\mathrm{P}<0.05$ when compared with the group i (untreated group) and group ii (acetaminophen treated group).

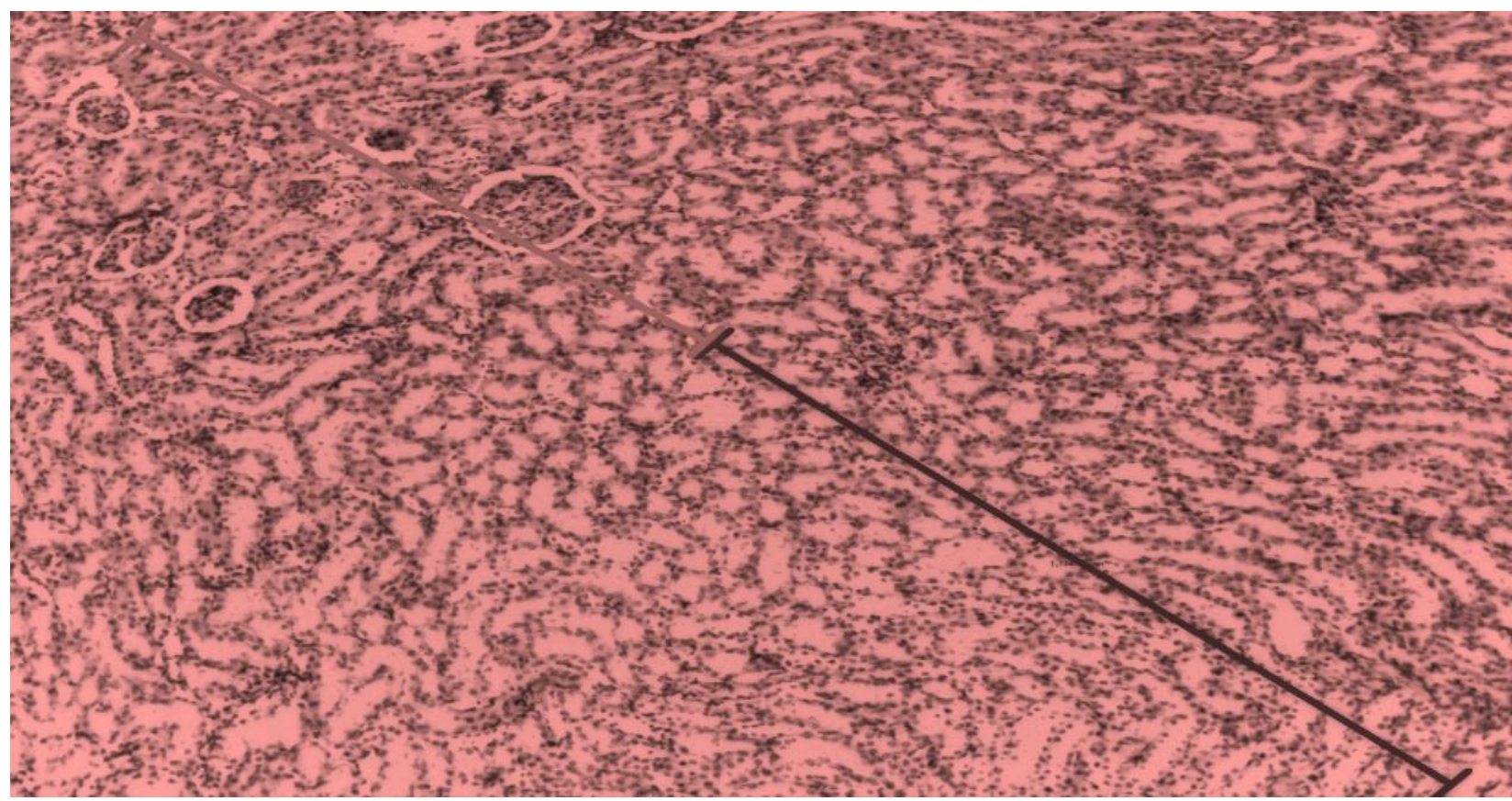

Figure 1: Stained cross section of kidney of the normal rats (group1) showing unremarkable kidney architecture with the cortex containing the glomerulus and the medulla containing the renal tubules $(\mathrm{H}$ and $\mathrm{E}$ Stain $(\times 100)$. 


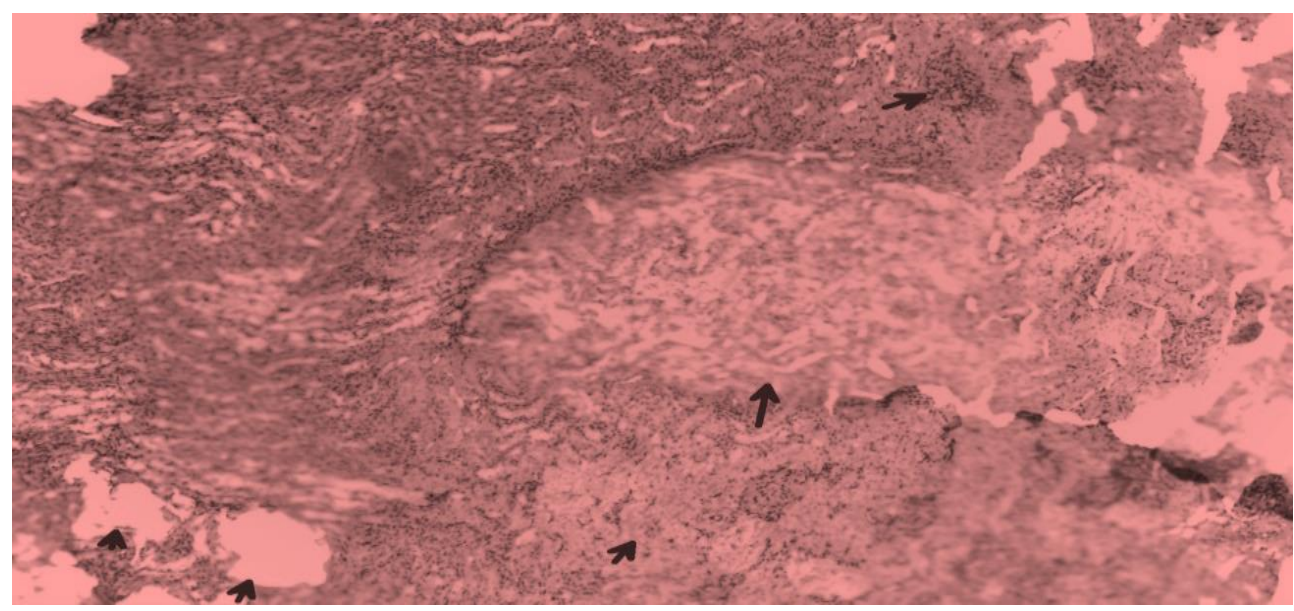

Figure 2: Stained cross section of the kidney of the acetaminophen induced injury rat showing areas of damaged kidney with the loss of normal architecture (Hand E Stain $(\times 100)$

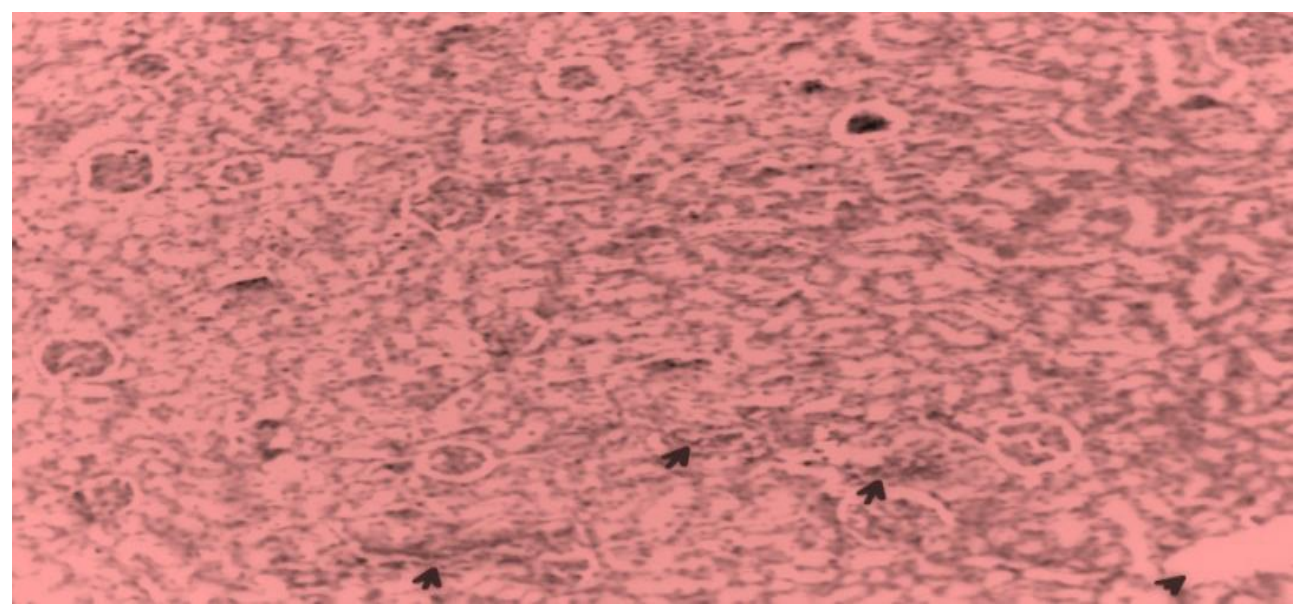

Figure 3: Stained cross section of kidney of acetaminophen induced rat administered with daily dose of $50 \mathrm{mg} / \mathrm{Kg}$ of Cassia sieberiana for two weeks showing moderately damaged kidney with the vascular congestion ( $\mathrm{H}$ and $\mathrm{E}$ Stain $(\times 100)$

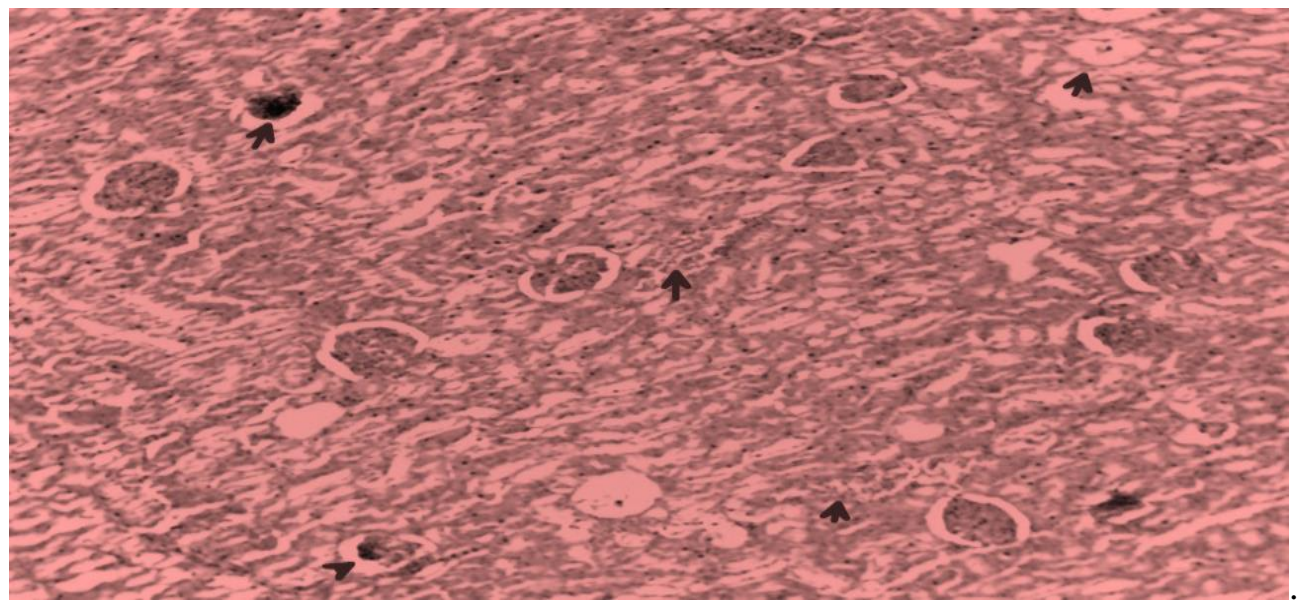

Figure 4: Stained cross section of kidney of acetaminophen induced injury rat administered with daily dose of $100 \mathrm{mg} / \mathrm{Kg}$ of Cassia sieberiana for two weeks showing areas of vascular congestion $(\mathrm{H}$ and $\mathrm{E}$ Stain $(\times 100)$ 


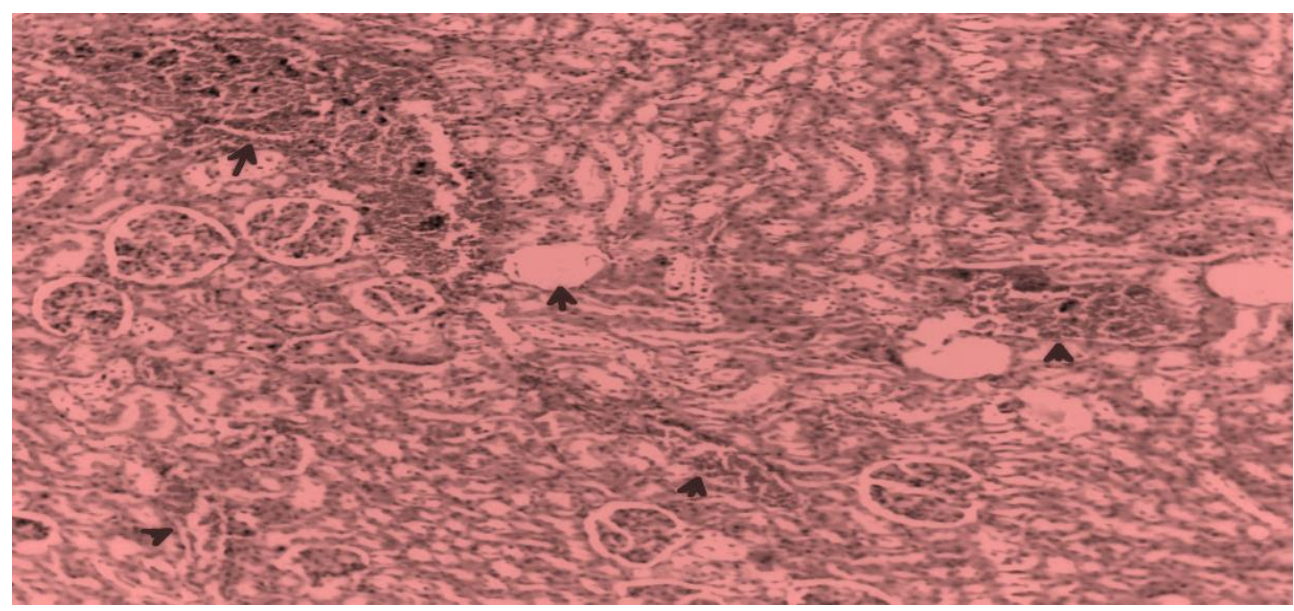

Figure 5: Stained cross section of kidney of acetaminophen induced injury rat administered with daily dose of $150 \mathrm{mg} / \mathrm{Kg}$ of Cassia sieberiana for two weeks showing areas moderately damaged kidney with vascular congestion $(\mathrm{H}$ and $\mathrm{E}$ Stain $(\times 100)$

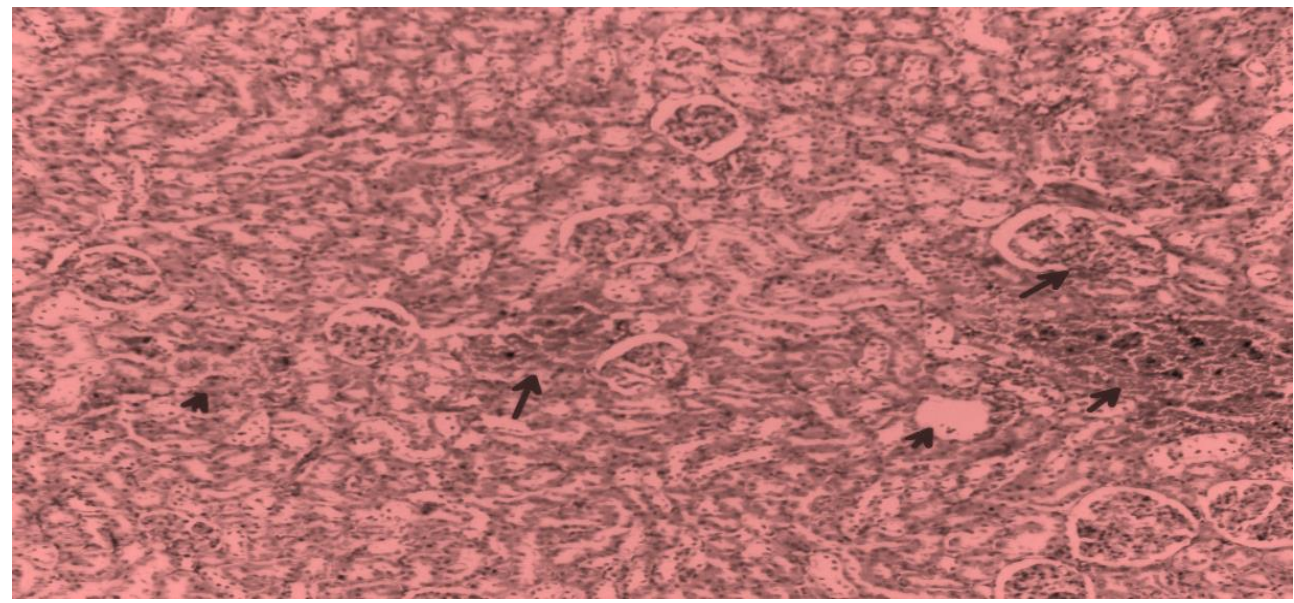

Figure 6: Stained cross section of kidney of acetaminophen induced injury rat administered with daily dose of $50 \mathrm{mg} / \mathrm{Kg}$ of Cassia sieberiana for four weeks showing areas of vascular congestion (H and E Stain $(\times 100)$

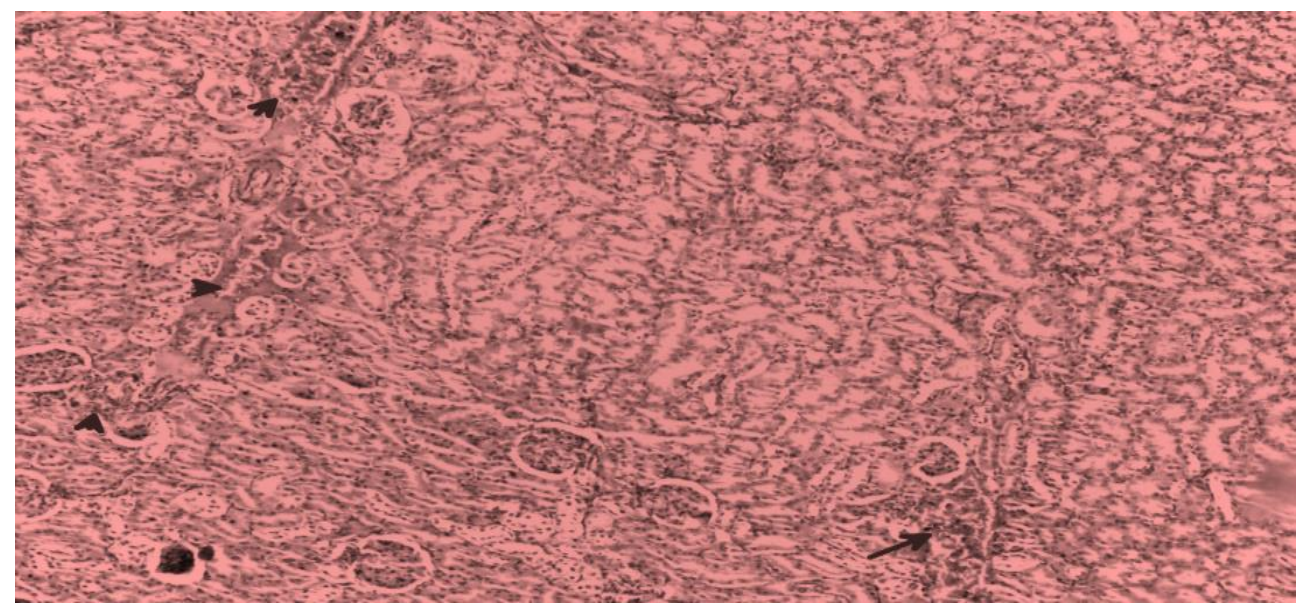

Figure 7: Stained cross section of kidney of acetaminophen induced injury rat administered with daily dose of $100 \mathrm{mg} / \mathrm{Kg}$ of Cassia sieberiana for four weeks showing areas of vascular congestion with mild kidney damage $(\mathrm{H}$ and E Stain $(\times 100)$ 


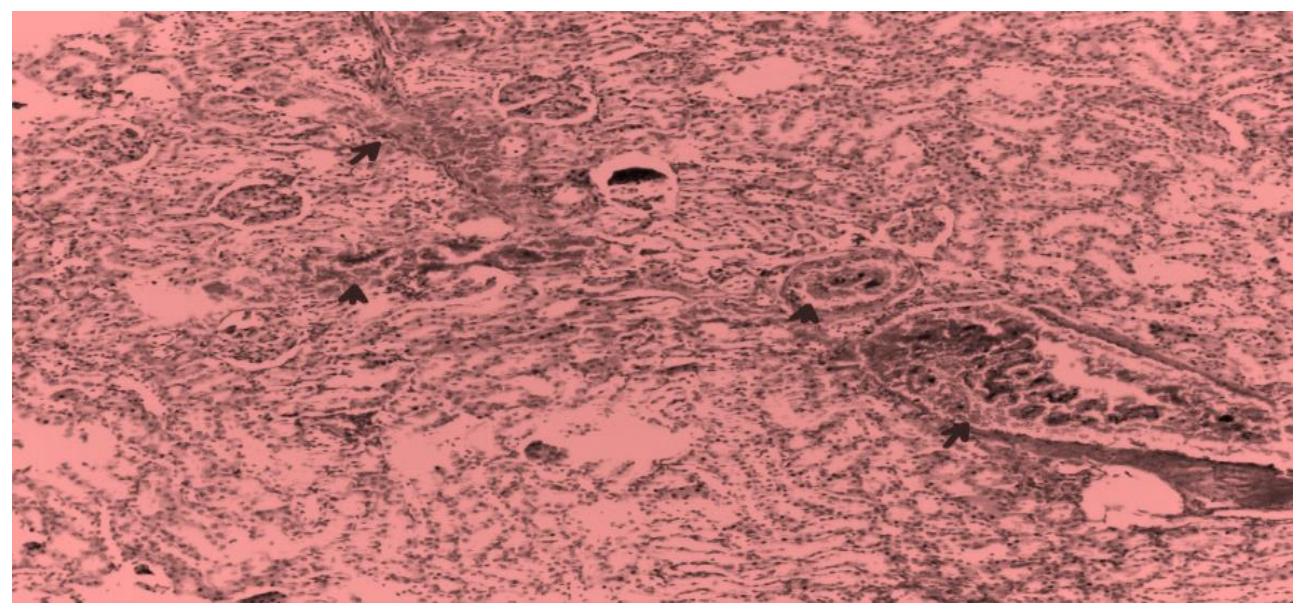

Figure 8: Stained cross section of kidney of acetaminophen induced injury rat administered with daily dose of $150 \mathrm{mg} / \mathrm{Kg}$ of Cassia sieberiana for four weeks showing areas of mild kidney damage with a vascular congestion. . $(\mathrm{H}$ and E Stain $(\times 100)$

\section{Discussion}

Kidneys are important organs in the body. They play a key role in metabolic processes. It helps in marinating homoestasis (Obidah et al., 2009). The LD 50 of the aqueous stem bark extract of Cassia sieberiana does not show any sign of toxicity or mortality up to a higher dose of $5000 \mathrm{mg} / \mathrm{kg}$ this agrees with the findings of (kofi et al., 2014) In contrast with the findings of Abdullahi et al., (2013) which showed that the $\mathrm{LD}_{50}$ of the leave of Cassia sieberiana was $960 \mathrm{mg} / \mathrm{kg}$. This difference may be due to the variation of the bioactive compounds of the different part of the same plant or differences of the environment. In the present study, Plasma urea, creatinine, $\mathrm{Na}^{+}, \mathrm{K}^{+}, \mathrm{Cl}^{-}$ and $\mathrm{HCO}_{3}{ }^{-}$levels were statistically increased $(\mathrm{p}<0.05)$ in a group treated with acetaminophen when compared with the normal control, this is due to ability of the high dose of acetaminophen to cause nephrotoxicity. Oxidative stress is reported to play a role in the pathogenesis of acetaminophen induced renal failure whose metabolism occur via cytochrome $\mathrm{p}_{450}$ enzymes in both liver and kidney. Acetaminophen leads to increase in peroxidative products leading to cell death and renal failure. Increased serum urea and creatinine have been linked to kidney disease (Obidah et al., 2009). Urea increases only when there is nephrotocixity, it is the first marker for renal failure (Daniel, 2018). In protein catabolism, Urea is the main end product. It represents $90 \%$ of the total urinary nitrogen excretion. Decrease in the rate of glomerular filtration as a result of kidney damage makes the kidney not to excrete urea and creatinine, therefore, leads to their increase in serum (Obidah et al., 2009).

After two and four weeks of the daily oral administration of Cassia sieberiana of 50,100 and $150 \mathrm{mg} / \mathrm{kg}$ showed a statistically decrease $(\mathrm{P}<0.05)$ mean serum levels of urea, creatinine, $\mathrm{Na}^{+}, \mathrm{K}^{+}, \mathrm{Cl}^{-}$and $\mathrm{HCO}_{3}{ }^{-}$when compared with the test control. The reduction of the urea and creatinine is due the presence of some phytochemicals in the extract that has nephrocurative effect. The induction of kidney damage and the nephrocurative effect of aqueous stem bark extract of cassia sieberiana were confirmed by histopathological analysis of the kidney of the rats. The induced kidney showed damage and the kidneys of the treated rats at the doses of $100 \mathrm{mg} / \mathrm{kg}$ and $150 \mathrm{mg} / \mathrm{kg}$ showed a mild damage after four weeks of the extract administration indicating some curative effects of the extract on the organs. 


\section{Conclusion}

The oral administration of aqueous stem bark extract of Cassia sieberiana has nephrocurative effects in rats. The presence of the phytochemicals may be responsible for their curative effects. The result of the $\mathrm{LD}_{50}$ shows no signs of toxicity therefore the plant is safe and can be applicable for medicinal uses

\section{References}

Abdulrazak N, Asiya UI, Usman NS, Unata IM, Farida A, (2015). Anti-plasmodial activity of ethanolic extract of root and stem back of Cassia sieberiana DC on mice, Journal of Intercultural Ethnopharmacology, vol: (2) pp. 96-101.

Auwioro, O.G. (2010). Histochemistry and tissue pathology: Principles and techniques.2nd Edition. University press delta state university, Abraka Nigeria. pp.561-568.

Bourhia, M., Haj Said, A. A., Chaanoun, A., El Gueddari, F., Naamane, A., Benbacer, L., and Khlil, N. (2019). Phytochemical Screening and Toxicological Study of Aristolochiabaetica Linn Roots: Histopathological and Biochemical Evidence. Journal of toxicology, 2019, 8203832.

Daniel A (2018) Effects of Pseudocedrela kotschyi stem bark on blood chemistry and histology of some organs in rats. J Clin Exp Tox.; 2(1): 25-31.

Edmund, T. N., Mark ., William, K and Caleb, M.A (2012) Antioxidant and gastric cytoprotective prostaglandins properties of Cassia sieberiana roots bark extract as an anti-ulcerogenic agent. BMC Complementary and Alternative Medicine 2012, 12:65.

Kofi, D., Loud, N.K., Okin, O., Wonder K.M., Abuts, A and Eric W .K. (2014). Acute and sub-Chronic Toxicity Studies of Aqueous Extract of Root Bark of Cassia Sieberiana D.C. in Rodents. Journal of Applied Pharmaceutical Science Vol. 4 (04), pp. 084-089.

Kuppuswamy, R.G., Anbuganapathi, V., Gokulakrishnan, B., Rajkapoor, B., Jayakar, H and Manian, S. (2003). Effect of dried fruits of solanum nigrum linn against $\mathrm{CCl} 4$ - induced hepatic damage in rats.Biol. and Pharmaceu. Bulletin 26, 1618-1619.

Lorke, D. (1983). A New approach to practical acute toxicity testing. Arch. toxicol. 53:275-287.

Madusolumuo, A.M., Nadro, S.M and Wurochekke, U.A (1999). Antihepatotoxic properties of Cassia sieberiana in acetaminophen treated rats. Nig. J. Biochem. Mol. Biol. 14: 21-25.

Marta J And Jerzy Z(2014).Paracetamol: Mechanism Of Action, Applications And Safety Concern actapoloniae. pharmaceutica Ñ Drug Research, Vol. 71 No. 1 pp. 11.

Mitchell, S. Sheppard, R., Vinay, K., Abbas, A., Abul, K. and Fausto, Nelson. R. (2011). Basic pathology. 8th edition. Chapter 11 Philadelphia: Saunders. 
Nisar, M. F., He, J., Ahmed, A., Yang, Y., Li, M., \& Wan, C. (2018). Chemical Components and Biological Activities of the Genus Phyllanthus: A Review of the Recent Literature. Molecules (Basel, Switzerland), 23(10), 2567.

Obidah, W., Saada, U.A. and Wurochekke, A.U. (2009). Toxic effects of aqueous stem bark extract of Cassia sieberiana on some biochemical parameters in rats. African Journal of Biochemistry Research 3(1), pp.229-231.

Ramesh, C., Gupta, D.C., Srinivas, N., Alan, Bensoussan., Kellie, B And Andbasi, D. R(2017) Interactions Between Antidiabetic Drugs And Herbs: An Overview Of Mechanisms Of Action And Clinical Implications. Diebetology and Metabolic Syndrome Vol 9. P 59

Sasikala, M., Annie, G., Praveen, Thaggikuppe., Yogendra, K., Vandana, K., Choudhary, Yesha and Rashmi, D (2019) Nephroprotective Effect Of Herbal Extract Eurycomalongifolia On Paracetamol-Induced Nephrotoxicity In Rats Evidence-based Complementary and Alternative Medicine Vol(3), pp.1-6. 